\title{
CURRICULUM REFORM IN THE DECENTRALIZATION OF EDUCATION IN INDONESIA: EFFECT ON STUDENTS'ACHIEVEMENTS
}

\author{
Anggia Utami Dewi \\ Universitas Padjadjaran, Indonesia \\ Seoul National University, South Korea \\ e-mail: anggia.utami@unpad.ac.id
}

\begin{abstract}
This study examines the estimated effect of curriculum reform in the Indonesian secondary education after the implementation of the decentralization policy in 2001. Whilst decentralization reform is argued to be positive for the improvement of school quality and efficiency due to more autonomy given for provincial and local governments, the empirical evidence on such reform towards the improvement of students' learning outcomes is very limited. Using the propensity score analysis, this study shows that the curriculum reform has not produced a substantial return in the aspect of improved learning outcomes. This finding resonates with the evidence from previous studies on the impact of decentralization on the education quality in Indonesia. Additionally, other findings present a positive effect of pre-school attendance on students' performance and the crucial issue of persisting gap on the education quality between regions even after almost twenty years of decentralization in the country.
\end{abstract}

Keywords: curriculum reform, decentralization, students'achievements, Indonesia.

\section{REFORMASI KURIKULUM PADA DESENTRALISASI PENDIDIKAN DI INDONESIA: DAMPAK PADA PRESTASI BELAJAR SISWA}

\begin{abstract}
Abstrak: Studi ini membahas estimasi pengaruh reformasi kurikulum dalam pendidikan menengah Indonesia setelah penerapan kebijakan desentralisasi pada tahun 2001. Walaupun reformasi desentralisasi dianggap positif untuk peningkatan kualitas dan efisiensi sekolah dengan otonomi yang diberikan kepada pemerintah provinsi dan daerah, bukti empiris tentang dampak reformasi tersebut bagi peningkatan hasil belajar siswa masih sangat terbatas. Dengan melakukan analisis skor kecenderungan, penelitian ini menunjukkan bahwa reformasi kurikulum belum menghasilkan pengembalian substansial dalam aspek peningkatan hasil belajar. Hal ini menggemakan bukti dari studi sebelumnya tentang dampak desentralisasi dalam kualitas pendidikan di Indonesia. Temuan lain juga menunjukan adanya efek positif dari partisipasi pendidikan pra-sekolah terhadap prestasi siswa dan masalah penting tentang kesenjangan kualitas yang masih ada antar daerah bahkan setelah hampir dua puluh tahun penerapan desentralisasi.
\end{abstract}

Kata Kunci: reformasi kurikulum, desentralisasi, prestasi belajar siswa, Indonesia.

\section{INTRODUCTION}

As one of the most prominent education reforms in many countries, education decentralization has become a popular topic in both scholarly and policy level of discourses. Associated closely with power distribution between different levels of government, decentralization in political aspect is perceived to undergo simultaneously with the democratization agenda (Channa, 2016; Jeong, Lee, \& Cho, 2017). The phenomenon also experienced by Indonesia, where after the hit of Asian financial crisis in 1997, the country had been through a rough democratization process. Ending the thirty-two years of authoritarian government under Suharto regime, Indonesia entered the Reformation Era, remarked by decentralization of most government functions, including education (Kristiansen \& Pratikno, 2006; Pradhan \& de Ree, 2014; de Ree, Muralidharan, Pradhan, \& Rogers 2014; Yeom, Acedo, Utomo, \& Yeom, 2002). Though the process of reformation had also external pushes from international agencies such as World Bank and International Monetary Funds, it was believed that decentralization was a wise decision considering the change in 
political system in the country which demand more democratic participation from its people.

In education, similar with other public sectors, decentralization is multifaceted and has both political and economic aspects (Jeong et al., 2017). Decentralized education has different forms depend on the national context of implementation, where two forms of the process could be seen in governance or more administrative aspect also in fiscal instrument, resulted further in different evaluation approach of such implementation (Jeong et al., 2017; Subijanto, 2010). Jeong et al., (2017) argued that while some countries might be both politically and fiscally centralized, some others might only have one aspect of decentralization. Diverse facets of decentralization practices can be also distinguished in particularly two forms: decentralization of education to local governments with focus on transfer of authority (Channa, 2016), and to schools in regards of 'school-based management' in the aspects of administrative, professional, community and balanced controls (Channa, 2016).

Apart from the devolving schemes, decentralization are argued to be a very important formula that could improve the provision of education services and in the end increase the quality of education (Channa, 2016; Jeong et al., 2017). Theoretically, by positioning educational decisions towards local governments, the decisions would be better meet the students' needs compared than homogenous standard set by the central government. Competition is expected to be increased among service providers, to ensure the delivery of high quality schooling. The accountability measurement of education delivery would also enhanced with the increasing participation from diverse stakeholders, including parents and community.

Since 2001, the administration of education in Indonesia has transformed from previously very centralized one towards decentralized system (Kristiansen \& Pratikno, 2006). Responsibilities in management and financial aspects of public education in early childhood, primary and secondary levels have been moved from central to local government. This change of policy was introduced as well by many governments in other countries, believing such strategies would benefited the improvement of education services delivery. In Indonesia, the central part of decentralized decision making in education is the School-Based Management (SBM) policy, where the empowerment of principals, teachers, also the involvement of parents and community are expected to have positive effects for autonomy and accountability in education delivery, and in the end produced better learning outcomes (Rahman, 2019).

In economics of education perspective, the school inputs remain the main part where government policy could play its role in education investment (Brewer \& McEwan, 2010). Teacher certification, school operational assistance, teacher competence test, in-service teacher development program, and one-year preservice teacher training, are some of the major policies taken by the Indonesian government to enhancing the quality education in the country (Kurniawati, Suryadarma, Bima, \& Yusrina, 2018). With the heavy investment on public education, teachers have benefited the most from the increase in education spending, from their increased salaries, also from more hiring and trainings, although, the investment seems to be ineffective towards the goal of better students learning (de Ree et al., 2015; Kurniawati et al., 2018).

On the other hand, curriculum reforms were part of the undergoing changes in Indonesian education, and it has strong relation with the dynamics of national level students' assessment in the country, as can be seen in Table 1. Curriculum reform is also a main part of the decentralization policy instrument, where in 2006, the school-based curriculum was introduced (Qoyyimah, 2018; Rahman, 2019). In 2006 School-based Curriculum, teachers are given more freedoms to plan the teaching and learning that is based on the condition of students also the school condition and environment (Wahyuni, 2015). In 2013, the Characterbased Curriculum was introduced to further complement the 2006 School-based Curriculum with emphasis on students' competence that should be accompanied with the strong character as well critical thinking, however the implementation of curriculum in schools level are still in development process.

By focusing on the curriculum reform in 2006 as significant feature of education decentralization in Indonesia (Amirrachman, Syafi'i, \& Welch, 2009), this study examines 
Table 1. National Curriculums and Examinations in Indonesia

\begin{tabular}{ll}
\hline Curriculum & Development of National Level Assessment \\
\hline 1947 Curriculum (1947-1968) & $1950-1964$ \\
1968 Curriculum (1968-1975) & $1965-1971$ (State Examination) \\
1975 Curriculum (1975-1986) & $1972-1979$ (School Examination) \\
1986 Curriculum (1986-1994) & $1980-2002$ (National Final Learning Evaluation) \\
1994 Curriculum (1994-2004) & $2003-2004$ (National Final Examination) \\
2004 Curriculum (2004-2006) & $2005-2020$ (National Examination) \\
2006 School-based Curriculum (2006-2013) & \\
2013 Curriculum (2013-...) & $2021-\ldots$ (Abolishment of National Examination) \\
\hline
\end{tabular}

Source: Alhadza \& Zulkifli (2017); Setiawan, Widjaja, Kusumajanto, \& Wahyono (2013); Wahyuni (2015)

the effect estimation of the curriculum reform to students' achievement in secondary schools by using the data from Indonesian Family Life Survey 5 (2014-2015). The main research question of this study is: "Has the curriculum reform implementation since 2006 in Indonesia effected students' performance?". With the evidence from Indonesia, the results of this study are expected to contribute to empirical inquiries of education investment and policies in developing countries, particularly under decentralization agenda.

\section{METHOD}

The data used in this study is from the fifth wave of Indonesian Family Life Survey (IFLS), which is an ongoing longitudinal survey that collects data at community, household, and individual levels (Strauss, Witoelar, \& Sikoki, 2016). There has been five waves of the survey so far. The first wave, IFLS1, was conducted in 1993-1994, and the sample represented around 83 per cents of Indonesian population in 13 out of 25 provinces in Indonesia by that time. The second wave of the survey was done four years after the IFLS1, and there was additional survey conducted in 1999 towards the 25 per cents of the subsample on the impact of economic crisis (IFLS2+), and the following wave was fully conducted in 2000. The IFLS4 was conducted in 2007-2008, and the last wave, IFLS5 was in 2014-2015. For the purpose of this study, the data of adult information on individual level where education related information in IFLS5 is utilized.

Sample is constructed through several steps. First, as the focus of this study is to see the curriculum reform in secondary education as part of decentralization, the respondents chosen here are those who graduated from junior and senior high schools between 1988-2015. Second, the observations in which national examination scores are not available were dropped. Third, the year of taking national examination is used as the dummy variable for the curriculum reform measurement. It is important to note that students take national examination with the curriculum first introduced to them when they enter school. For secondary schools, it means there are three years gap of the introduced curriculum to their year of taking national examination. As the new curriculum named "School-based Curriculum" as part of decentralization reform was introduced and formally legalized in 2006, therefore students who experienced the curriculum reform under decentralization policy were those who took the national examinations after 2009. Those who took the examinations before that were the control group in this study. The variables from IFLS5 Book 3A (Adult Information Part 1) that are chosen as measurement in this study are shown in Table 2.

In this study, propensity score analysis is conducted to estimate the effect of curriculum reform as part of education decentralization on students' performances in secondary level. The analysis is one technique of causal effects' estimations that allow valid casual inference based on defining the counterfactual group through a quasi-experiment on observational data (Cordero, Cristóbal, \& Santín, 2018). With respect to observed covariates, both propensity score models were administered to reduce the selection bias by balancing the treatment and the control groups to look like the full sample (Adelson, 2013; Guo \& Fraser, 2014; Rosenbaum \& Rubin, 1983; Xie, Brand, \& Jann, 2012). 
Table 2. Measurements and Variables

\begin{tabular}{|c|c|c|}
\hline Measurements & Variables and Descriptions & \\
\hline Student characteristics & $\begin{array}{l}\text { Sex }(1=\text { Female, } 0=\text { Male }) \\
\text { Kindergarten attendance }(1=\text { Attend, } 0=\text { Do not attend } \\
\text { Language capacity (reading and writing in other language), } \\
(1=\text { yes, } 0=\text { no }) \\
\text { Phone ownership }(1=\text { yes, } 0=\text { no }) \\
\text { Internet access availability }(1=\text { yes, } 0=\text { no })\end{array}$ & $\begin{array}{l}\text { Control } \\
\text { variables }\end{array}$ \\
\hline School characteristics & $\begin{array}{l}\text { School type }(1=\text { public, } 0=\text { private and others }) \\
\text { Average hours spent in school } \\
\text { Class size } \\
\text { Province of school location -Region is divided by Human } \\
\text { Development Index (HDI), (low, medium, high) }\end{array}$ & \\
\hline Students' outcomes & $\begin{array}{l}\text { National examination score (average in overall score) } \\
\text { Mathematic score } \\
\text { Bahasa Indonesia score } \\
\text { English score }\end{array}$ & $\begin{array}{l}\text { Dependent } \\
\text { variables }\end{array}$ \\
\hline Curriculum reform & $\begin{array}{l}\text { Year of taking national examination }(\ldots-2008=\text { No reform, } \\
2008-2015=\text { reform })\end{array}$ & $\begin{array}{l}\text { Treatment } \\
\text { variable }\end{array}$ \\
\hline
\end{tabular}

Source: Strauss et al., (2016)

The analysis process started with preliminary descriptive analyses for all variables after the deletion of missing cases (see Table 3 ), and then the study conducted the ordinary least squares (OLS) regression with and without control variables as the first model, the propensity score matching model as the second model, and the propensity score weighting models as the third one (see Table 4). For the propensity score weighting models, logistic regression analysis was conducted with covariates to examine the adjusted differences in characteristic of students who experienced curriculum reform and not, include to estimate the propensity scores.

The next step was to conduct a propensity score analysis with weighting process that is often called by inverse probability of treatment weighting (Fan \& Nowell, 2011; Hong, 2012; Rosenbaum \& Rubin, 1984). In the end, the OLS regression analysis were conducted to estimate the effect of curriculum reforms in three aspects: average treatment effect (ATE); average treatment effect for the treated (ATT); and average treatment effect on the controlled (ATC).

Based on the $R$-squared of all models, the weighting procedure presented the most representative model that could explain the effect estimation. The analysis then went further by estimating the effects of curriculum reform in overall subjects (mean score), also in each individual subject (see Table 5). The final conduct of analysis was as presented in Table 6, where the groups of treated after the curriculum reform is divided in yearly basis (from 2009 onwards), to see the development of policy on curriculum reform implementation effect on annual level.

\section{FINDINGS AND DISCUSSION Findings}

Table 3 presents the descriptive analysis of variables used in this study. After the data is constructed, the number of observations of secondary school students with national examination scores available are 6081, with the mean of total score is 7.029 out of 9.998 maximum. Among all subjects, Bahasa Indonesia score has the highest mean whilst English has the lowest one. Among observed sample, around 54 per cents are women, more than 68 per cents attended public schools, with average hours spent in schools are 6.2 hours. More than fifty per cents also attended kindergarten, and those who took national examination after the curriculum reform in 2006 was implemented contributed to more than eighty per cents of sample. This unbalanced condition between the control and treatment groups are resolved further through the propensity score analysis. 
Table 3. Descriptive Statistics

\begin{tabular}{|c|c|c|c|c|c|}
\hline Variables & $N$ & Mean & S.D. & Min & Max \\
\hline Bahasa score & 6,081 & 7.229 & 1.239 & .000 & 9.998 \\
\hline English score & 6,081 & 6.878 & 1.476 & .000 & 10.000 \\
\hline Math score & 6,081 & 6.980 & 1.764 & .000 & 10.000 \\
\hline National examination score & 6,081 & 7.029 & 1.204 & .000 & 9.998 \\
\hline Curriculum reform & 6,058 & .814 & .389 & .000 & 1.000 \\
\hline Kindergarten & 6,081 & .535 & 499 & .000 & 1.000 \\
\hline Female & 6,081 & .537 & .499 & .000 & 1.000 \\
\hline Public school & 5,559 & .682 & .465 & .000 & 1.000 \\
\hline Reading in other language & 6,081 & .893 & .310 & .000 & 1.000 \\
\hline Writing in other language & 6,081 & .862 & .345 & .000 & 1.000 \\
\hline Phone & 6,081 & 951 & .216 & .000 & 1.000 \\
\hline Internet & 6,081 & .862 & .345 & .000 & 1.000 \\
\hline Class size & 5,904 & 33.747 & 11.970 & 3.000 & 401.000 \\
\hline Average hours & 6,002 & 6.207 & 1.281 & 1.000 & 11.000 \\
\hline Region HDI & 623 & 1.878 & .650 & 1.000 & 3.000 \\
\hline
\end{tabular}

The main research question of this study is answered through the conduct of several models of causal inference as seen in Table 4. After the balance of observation numbers between the treatment and control groups, from Table 4 we can assess that the robust model that can explain the data analysis better is the propensity score weighting. For the causal inference, it is shown that curriculum reform has significantly negative effect to students' performance. However, as the variable curriculum reform is only divided in two categorical of students who took examination on 2008 (and before) and 2009 (and after), further appraisals are needed to present more detail pictures on this result, as the analysis is exercised through the division of reform by yearly basis (see Table 6).

Table 4. Curriculum Reforms and Students' Outcomes

\begin{tabular}{|c|c|c|c|c|c|}
\hline Variables & OLS (1) & PSM (2) & ATE (3) & ATT (4) & ATC (5) \\
\hline Curriculum reform & .010 & -.278 & $-.333 * * *$ & $-.334 * * *$ & .019 \\
\hline & $(.357)$ & $(.304)$ & $(.109)$ & $(.107)$ & $(2.690)$ \\
\hline Kindergarten & $.235^{* *}$ & $468^{* *}$ & $.429 * * *$ & $384 * * *$ & $311 * *$ \\
\hline & $(.112)$ & $(.192)$ & $(.125)$ & $(.115)$ & $(.145)$ \\
\hline Female & .122 & -.144 & $-.294 * *$ & $-.244 * *$ & .144 \\
\hline Public school & -006 & -012 & (.110) & $\begin{array}{l}(.100) \\
-009\end{array}$ & $(.114)$ \\
\hline & $(.010)$ & (.010) & $(.017)$ & $(.012)$ & (.120) \\
\hline Reading in other language & $\begin{array}{l}.639 * * * \\
(239)\end{array}$ & .376 & & $\begin{array}{l}.351 \\
(283)\end{array}$ & \\
\hline Writing in other language & $\begin{array}{l}-.296 \\
.210)\end{array}$ & $\begin{array}{l}.029 \\
(.289)\end{array}$ & $\begin{array}{l}.253 \\
(.273)\end{array}$ & $\begin{array}{l}.046 \\
. .236)\end{array}$ & $\begin{array}{l}-.157 \\
(277)\end{array}$ \\
\hline Phone & $\begin{array}{l}-.143 \\
(.280)\end{array}$ & $\begin{array}{l}-.065 \\
(.267)\end{array}$ & & $\begin{array}{l}-.237 \\
(.343)\end{array}$ & \\
\hline Internet & $\begin{array}{l}.092 \\
(.235)\end{array}$ & $\begin{array}{l}. .104 \\
(.264)\end{array}$ & & $\begin{array}{l}-.054 \\
(.289)\end{array}$ & \\
\hline Class size & $\begin{array}{l}.007 \\
(.005)\end{array}$ & & $\begin{array}{l}.000 \\
(.005)\end{array}$ & $\begin{array}{l}.001 \\
(.005)\end{array}$ & $\begin{array}{l}.021 * * * \\
(.007)\end{array}$ \\
\hline Average hrs & $\begin{array}{l}.137 * * * \\
(.047)\end{array}$ & & $\begin{array}{l}.061 \\
(.054)\end{array}$ & $\begin{array}{l}.101 * * \\
(.049)\end{array}$ & $\begin{array}{l}.141^{* * *} \\
(.055)\end{array}$ \\
\hline Region HDI & $\begin{array}{l}.033 \\
(.082)\end{array}$ & $\begin{array}{l}-.452 * * \\
(.186)\end{array}$ & $\begin{array}{l}-.433^{* * * *} \\
(.093)\end{array}$ & $\begin{array}{l}-.358^{* * * *} \\
(.086)\end{array}$ & $\begin{array}{l}-.011 \\
(.089)\end{array}$ \\
\hline Constant & $\begin{array}{l}5.409 * * * \\
(.628)\end{array}$ & $\begin{array}{l}7.755 * * * \\
(.657)\end{array}$ & $\begin{array}{l}7.476^{* * * *} \\
(.540)\end{array}$ & $\begin{array}{l}7.213^{* * *} \\
(.617)\end{array}$ & $\begin{array}{r}5.324^{*} \\
(2.737)\end{array}$ \\
\hline Observations & 611 & 621 & 505 & 611 & 504 \\
\hline$R$-squared & .047 & .127 & .182 & .162 & .050 \\
\hline Propensity score analysis & $\mathrm{NO}$ & YES & YES & YES & YES \\
\hline
\end{tabular}

Note: Dependent/ treatment variable is Curriculum Reform where 1 is for students who took national exam after the reform and 0 is for those who took exam before the reform. Standard errors in parentheses, ${ }^{* * *} p<.01, * * p<.05,{ }^{*} p<.1$ 
The analysis also presents that students who attended kindergarten tend to perform better than who did not. It supports the argument of investment on early childhood education in Indonesia (Nakajima, Hasan, Jung, Brinkman, Pradhan, \& Kinnell, 2019). In model 3 and 4, it is also shown that female students comparatively have lower performance than their male peers. Also, the student who come from schools in lower HDI region, tend to perform lower, and it pictures the gap of quality education among region in Indonesia, which has been an issue for so many years (Amirrachman et al., 2009; Kurniawati et al., 2018; Yeom et al., 2002).

In Table 5, the analysis of propensity score weighting on Average Treatment Effect (ATE) is presented. It can be seen that curriculum reform has a relatively small effect on students' performances in Bahasa Indonesia. However, this might be explained by the fact that national language proficiency of students are relatively higher. For negative effect estimation of curriculum reform, the most prevalent result is in students' mathematics performance.

It also estimated that the effect of attending kindergarten is significant on students learning outcomes in mathematics and English, while not significant for Bahasa Indonesia's performances. The results also show consistency in the unequal quality of education among regions. To explain the insignificant effects and some negative effects of curriculum reforms on students' national exam score from year 2009-2015, detailed analysis is conducted and presented in Table 6 .

Table 5. Curriculum Reforms and Students' Outcomes: Comparison by Subjects

\begin{tabular}{|c|c|c|c|c|}
\hline Variables & Overall & Math & Bahasa & English \\
\hline Curriculum reform & $-.333 * * *$ & $-.852 * * *$ & $.195^{*}$ & $-.343 * * *$ \\
\hline & (.109) & $(.169)$ & (.107) & $(.131)$ \\
\hline Kindergarten & $429 * * *$ & $.704 * * *$ & .054 & $.530 * * *$ \\
\hline & $(.125)$ & $(.194)$ & $(.122)$ & $(.150)$ \\
\hline Female & $-.294 * *$ & .070 & $-.385 * * *$ & $-.568 * * *$ \\
\hline Public & $(.116)$ & $(.179)$ & $(.113)$ & $(.139)$ \\
\hline Public & $\begin{array}{l}.005 \\
(017)\end{array}$ & .0111 & -.009 & .012 \\
\hline Writing in other language & $\begin{array}{r}.0113 \\
.253 \\
(273)\end{array}$ & $\begin{array}{r}.020 \% \\
(4522)\end{array}$ & $\begin{array}{r}.0135 \\
.0136)\end{array}$ & $\begin{array}{l}.020) \\
-.011 \\
(.327)\end{array}$ \\
\hline Class size & .000 & .002 & $\begin{array}{l}(.200) \\
-.006\end{array}$ & $\begin{array}{l}.021) \\
.006\end{array}$ \\
\hline & $(.006)$ & $(.008)$ & $(.005)$ & $(.006)$ \\
\hline Average hours & $\begin{array}{l}.061 \\
(.054)\end{array}$ & $\begin{array}{l}-.091 \\
-.083)\end{array}$ & $\begin{array}{l}-.025 \\
(.052)\end{array}$ & $\begin{array}{l}.298 * * * \\
(.064)\end{array}$ \\
\hline HDI region & $-.433 * * *$ & $-.556 * * *$ & $-.451 * * *$ & $-.293 * * *$ \\
\hline & $(.093)$ & $(.144)$ & $(.091)$ & $(.111)$ \\
\hline Constant & $7.476 * * *$ & $8.061 * * *$ & $8.748 * * *$ & $5.620 * * *$ \\
\hline Observations & $\begin{array}{c}.540) \\
505\end{array}$ & $(.835)$ & $(.527)$ & $(.646)$ \\
\hline$R$-squared & .182 & .128 & $\begin{array}{l}505 \\
.116\end{array}$ & $\begin{array}{l}505 \\
.249\end{array}$ \\
\hline Weighting & YES & YES & YES & YES \\
\hline
\end{tabular}

Table 6. Curriculum Reform and Students' Outcomes from 2009-2015

\begin{tabular}{|c|c|c|c|c|c|c|c|}
\hline Variables & 2009 & 2010 & 2011 & 2012 & 2013 & 2014 & 2015 \\
\hline Curriculum reform & .204 & .210 & .197 & .174 & $-1.064 * * *$ & $-.649 * * *$ & .210 \\
\hline Kindergarten & .458 & $\begin{array}{l}(.294) \\
-.023\end{array}$ & $.453)$ & $\begin{array}{l}.217) \\
.166\end{array}$ & $.500 * *$ & $.484 * *$ & $\begin{array}{l}.000) \\
.318\end{array}$ \\
\hline Female & $\begin{array}{l}(.531) \\
.594\end{array}$ & $\begin{array}{l}(.380) \\
-.465\end{array}$ & $\begin{array}{l}(.436) \\
-.338\end{array}$ & $\begin{array}{l}(.261) \\
-.417^{*}\end{array}$ & $\begin{array}{l}(.233) \\
-.244\end{array}$ & $\begin{array}{l}(.216) \\
-.217\end{array}$ & $\begin{array}{l}(.784) \\
.254\end{array}$ \\
\hline & $(.539)$ & (334) & $(.456)$ & $(.230)$ & $(.216)$ & $(.205)$ & $(.726)$ \\
\hline Public school & -.163 & .161 & $-.037^{\prime}$ & 0368 & 016 & $.373^{*}$ & .019 \\
\hline Writing in other language & $(.579)$ & $1.287 *$ & $1.728 * *$ & $\begin{array}{l}(.240) \\
.363\end{array}$ & $\begin{array}{l}.01 /) \\
.329\end{array}$ & $\begin{array}{l}(.211) \\
-.186\end{array}$ & $\begin{array}{l}(.875) \\
.923\end{array}$ \\
\hline & & (.692) & $(.845)$ & $(.527)$ & (.634) & $(.402)$ & $(1.004)$ \\
\hline Class size & -.017 & -.001 & .0030 & -.006 & $-.030 * *$ & $-.026^{*}$ & $-.100 *$ \\
\hline & $(.045)$ & $(.032)$ & $(.008)$ & $(.016)$ & $(.014)$ & $(.014)$ & $(.048)$ \\
\hline Average hours & .236 & $\begin{array}{l}-.124 \\
(136)\end{array}$ & $\begin{array}{l}0177 \\
(194)\end{array}$ & $\begin{array}{l}.050 \\
(115)\end{array}$ & $\begin{array}{l}101 \\
(099)\end{array}$ & .114 & .120 \\
\hline Region HDI & -.568 & $-.867 * *$ & -.242 & -.252 & $-.374 * *$ & $-.487 * * *$ & -1.230 \\
\hline Constant & $6.925 * *$ & $8.900 * * *$ & $5.824 * * *$ & $7.602 * * *$ & $8.078 * * *$ & $8.391 * * *$ & $11.020^{*}$ \\
\hline Obs & & $\begin{array}{l}(1.6 \%) \\
46\end{array}$ & $(1.720)$ & $(1.257)$ & $\begin{array}{l}(1.128) \\
151\end{array}$ & $\left.\begin{array}{l}(1.040) \\
156\end{array}\right)$ & $(5.154)$ \\
\hline & .246 & .338 & .238 & .107 & .269 & .196 & .731 \\
\hline Weighting & YES & YES & YES & YES & YES & YES & YES \\
\hline
\end{tabular}


In Table 6, the data of students who took national examination is divided into yearly basis (before 2009 with 2009, before 2009 with 2010 , cont.). The results present that generally there were no statistically significant effect of curriculum reform on students' performance in overall national examination score from 20092012. However, in 2013 and 2014, the estimating effect of curriculum reform on students' performances are statistically significant, in negative direction. The possible explanations of these results could be on the fact that started in 2013 , there was a policy intervention on the conduct of national examination, where the examination questions have more types and there were also more invigilator during the exams. However, there were problems in the conduct of national examination in 2013 due to the mismanagement from the Ministry of Education, which had resulted in the delay of the examination in many regions (Suryadi, 2013). This affected students psychologically, because they had prepared for the examination and on the day of the exam, the exam sheets were not arrived yet. Another cases were the incomplete exam sheets or misdistribution of exam sheets.

\section{Discussion}

The origin of decentralization in Indonesia could be traced far before the so called 'Bing Bang' decentralization took place in Indonesia due to the significant economic and political transition during the beginning of the new millennia Fitrani, Hofman, \& Kaiser, 2005; Hofman \& Kaiser, 2004). The concept of 'regional autonomy' was included in the Constitution Law in 1945, the recognition of extensive autonomy in different tiers of government was also introduced in the Government Law No. 1/1957, but finally the system needed to be centralized again due to many political unrests. Even during the New Order regime where the government was heavily centralized and authoritarian in nature, the local autonomy was once again passed into legal base under the People's Consultative Assembly in 1974. Law No. 5/1974, even in practice, the exercise of decentralization was introduced in 1995 (Fitrani et al., 2005; Skoufias, Narayan, Dasgupta, \& Kaiser, 2011). It was the fall of New Order regime as the aftermath of Asian Financial Crisis in 1997 that had resulted in a major breakthrough of governance system in Indonesia.
The structural adjustment requirement from the international agencies added the extreme transformation of Indonesia from previously one of the most centralized systems to one of the most decentralized ones (Hofman \& Kaiser, 2004).

In education sector, the decentralization started took place after the enactment of Law on Decentralization in 2001, marked by the transferred administrative and fiscal power and responsibility for health and public education to districts governments, where teacher salaries, general school operational costs and management are handled in district level (Leer, 2016). In 2003, the Constitution Law No. 20 was enacted and it stated the reform of education educational system that should be based on democratic, decentralized and socially just principles (Rahman, 2019). The school-based management policy has designed the autonomous school governance where principals have primary responsibilities to work and collaborate with other school stakeholders, such as teachers, parents, local communities under the establishment of school committee (Leer, 2016). In ensuring the better and more heterogenous education delivery to diverse students across the country, the curriculum that based on competency occurred in 2004, and finally the School-Based Curriculum was legalized in 2006 with features of decentralized curriculum were emphasized on development of localized curriculum with more autonomies given to teachers in doing so (Qoyyimah, 2018; Rahman, 2019; Yeom et al., 2002).

Due to the pro and contra in the mandatory national examination as main instrument of quality education assessment, for example, after the Supreme Court Decision in 2010 , there had been fundamental changes in the graduation criteria and the percentage of national examination score that is being counted as passing criteria (Alhadza \& Zulkifli, 2017). In 2013, the government also had made several changes in the national examination to reduce leaking, cheating, and score manipulations (Alhadza \& Zulkifli, 2017). Whilst in 2015, the Computer-Based Testing was introduced to enhance the efficiency and effectivity of the conduct of national examination, also to ensure fairness and reduce malpractices of the examination (Kurniawati et al., 2018). After the new administration of government in 2019, the 
appointed Minister of Education and Culture has finally decided the abolishment of national examination in Indonesia starting from 2021 to ensure the rights of continuing education for all students, and change the evaluation through competence assessment and character survey. However, in response towards Covid-19 disruption, the government decided that this year (2020) the national examination for primary and secondary levels are cancelled (Wajdi, Kuswandi, Faruq, Zulhijra, Khairudin, \& Khoiriyah, 2020).

Regardless heavy investments and decentralization efforts in making better access to quality education, the returns to that investments are argued to be the main problems that need to be addressed. The little experience of local democracy, unclear legislative guidelines, lack of local capacity building are mentioned as the unpreparedness of decentralization policy that has resulted the failure of policy implementation (Amirrachman et al., 2009). Further, the corruption issues also have proven to diminishing the effectiveness of public spending on education in Indonesia (Suryadarma, 2012). In the case of effects of decentralization policies towards students' learning, many empirical inquiries have shown very limited, almost zero evidences of how such policies could improve Indonesian students' performances in national and international level assessments (del Granado, Fengler, Ragatz, \& Yavuz, 2007; Chen, 2011; de Ree et al., 2015; Kurniawati et al., 2018; Kusumawardhani, 2017; Leer, 2016; Sirait, 2016; Suryadarma, 2012).

This study has the objective to provide a robust analysis on effect estimation of curriculum reform under decentralization policy on students' learning outcomes in Indonesia. In policy level, there are different instruments that government can exercise to achieve the goal of decentralization efforts, and curriculum reform is one of the significant feature (Amirrachman et al., 2009). Curriculum reform reflects the expectation of educational changes, which would affect teacher education, teaching content and practices, school leadership, even infrastructure, and most importantly educational outcomes (Qoyyimah, 2018). The change in curriculum, with the aim to increase better learning, certainly has complex mechanism that connect each other, therefore there is should be no simple direct correlation of one aspect under the change.
However, under the context of decentralization, the autonomy of school and teacher is central on curriculum reform. By granting autonomy to schools in varying their curriculum depends on their students' needs and local context, students' performance in the end should be improved. Some evidences can be seen in the case of curriculum reform with school autonomy plays important role towards learning performances in England and East Asian countries (You \& Morris, 2016).

From this research findings, we can see some important points to be addressed. First, there has been a very dynamic development in terms of curriculum reform and national examination in Indonesian education for the past twenty years. The reforms and changing policy, however, have gaps between the intention and implementation. Some argues that the policy initiatives have been changing depend on who are the policy makers rather than to serve the main purposes of making a better education system in the country (Suryadi, 2013). The policies have been politicized and unsustainable, therefore the roots of low quality education have not been resolved yet. For example, as discussed in the findings part, the issue of chaotic conduct of national examination in 2013 and 2014 was one impression of the poor management in Indonesian education system during that period (Lestarini, 2014).

Second, whilst there are evidences where curriculum reform under decentralization brought positive effects to the students' outcomes (Rahman, 2019; You \& Morris, 2016), the underlying condition is adequate understanding and quality of teachers as the main education resources to implement the policy direction. Teachers' professionalism and capacity development to follow the reformation should be highlighted, however, from the evidences of school-based management and decentralized curriculum in Indonesia, lack of socialization and sufficient supports have hindered the accomplishment of curriculum reform (Rahman, 2019; Retnawati, 2016). The issues of teachers' quality and ability to adapt the reform are mentioned to be the challenges of improving students' learning outcomes in Indonesia (Rahman, 2019). With higher expectation and burden for teachers in adjusting the needs of their students also in fulfilling the targets set by 
the government, the realization of making the reform effective and achieving its' goals is not an easy task to do.

Third, the results also presented the important aspect of early childhood education as investment on school readiness, which will be beneficial for students' learning performance in later years. This could be one example of fruitful policy implementation on increasing early childhood education access as part of Indonesian government priorities over the last decade (Nakajima et al., 2019). However, it should be noted that the issue of inequality of access and quality education among different group remain crucial challenges to be addressed. The gap between students from higher and lower quintiles, also from urban and rural areas, still hamper the achievement of development goals in education in Indonesia. The significant results on students' outcomes difference based on the regions where the schools are located continuously resonates the evidences from previous studies on decentralization impact in education quality in Indonesia, and the issue of inequality among regions in Indonesia (Aditomo \& Faridz, 2019; BPS, 2019).

\section{CONCLUSION}

Indonesia has been experiencing a tremendous increased of investment in public education during the past two decades, together with the decentralization on its governance. While positive appraisals were given to the country in presenting a 'quite good' case study in developing economies of decentralization reform, the empirical evidences of return of investment in increasing quality education is still being questioned. This study reveals that, similar with other interventions of decentralization policy in Indonesia, the curriculum reform has not produced a substantial return in the aspect of improved learning outcomes. Further, this study discusses the issue of unsustainable policy direction and teachers' ability to perform the curriculum design and objective, future studies might explore other dimensions from different perspectives.

Curriculum implementation under decentralized education, expect schools and teachers to develop their own approaches that fit the needs of their students. It also expect students to develop their competences while also improving students' learning outcomes. Therefore, the issue of teachers' quality and their ability to conduct the curriculum reform content is crucial to be addressed. The sufficient supports from the national and institutional levels should be prioritized, therefore the teachers would not be further burdened by the heavy administrative concerns, but could focus on cultivating their professional skills and judgment to carry out the reform successfully. As also argued in other decentralization studies, the accountability measurement on any intervention should be added and taken into serious manner, so the investment could have resulted in enhancement of students' performance and overall quality of education.

\section{REFERENCES}

Adelson, J. L. (2013). Educational research with real-world data: Reducing selection bias with propensity scores analysis. Practical Assessment, Research, and Evaluation, 18(15), 1-11. https://doi. org/10.7275/4nr3-nk33.

Aditomo, A., \& Faridz, N. F. (2019). Ketimpangan mutu dan akses pendidikan di Indonesia: Potret berdasarkan survei PISA 2015. [Inequality in quality and access to education in Indonesia: A portrait based on the 2015 PISA survey]. Kilas Pendidikan, 17, 1-8. https://doi. org/10.31227/osf.io/k76g3.

Alhadza, A., \& Zulkifli, M. (2017). National examination and the quality of education in Indonesia. Advances in Social Sciences Research Journal, 4(21), 1-12. https:// journals.scholarpublishing.org/index.php/ ASSRJ/article/download/3613/2286.

Amirrachman, A., Syafi'i, S., \& Welch, A. (2009). Decentralising Indonesian education: The promise and the price. In J. Zajda \& D. T. Gamage (Eds.). Decentralisation, school-based management, and quality. Netherlands: Springer, pp. 141-157. https://doi.org/10.1007/978-90-4812703-0 8.

BPS (Badan Pusat Statistik). (2019). Potret pendidikan: Statistik pendidikan Indonesia 2019. [Image of education: 
Statistic of Indonesian education 2019]. Jakarta, Indonesia: Author.

Brewer, D., \& McEwan, P. (2010). Economics of education. San Diego, CA: Elsevier.

Channa, A. (2016). Popularity of the decentralization reform and its effects on the quality of education. PROSPECTS, 46(1), 131-147. https://doi.org/10.1007/ s11125-016-9380-7.

Chen, D. (2011, September). School-based management, school decision-making and education outcomes in Indonesian primary schools (Policy Research Working Paper No. 5809). Word Bank. https://doi.org/10.1596/1813-9450-5809.

Cordero, J. M., Cristóbal, V., \& Santín, D. (2018). Causal Inference on education policies: A survey of empirical studies using PISA, TIMSS and PIRLS. Journal of Economic Surveys, 32(3), 878-915. https://doi.org/10.1111/joes.12217.

de Ree, J., Muralidharan, K., Pradhan, M., \& Rogers, H. (2015, December). Double for nothing? Experimental evidence on the impact of an unconditional teacher salary increase on student performance in Indonesia (Working Paper No. w21806; p. w21806). Cambridge, MA: National Bureau of Economic Research. https:// doi.org/10.3386/w21806.

del Granado, F. J. A., Fengler, W., Ragatz, A., \& Yavuz, E. (2007, July). Investing in Indonesia's education: Allocation, equity, and efficiency of public expenditures (MPRA Paper No. 4372). Jakarta, Indonesia: The World Bank. https://doi. org/10.1596/1813-9450-4329.

Fan, X., \& Nowell, D. L. (2011). Using propensity score matching in educational research. Gifted Child Quarterly, 55(1), 74-79. https://doi. org/10.1177/0016986210390635.

Fitrani, F., Hofman, B., \& Kaiser, K. (2005). Unity in diversity? The creation of new local governments in a decentralising Indonesia. Bulletin of Indonesian
Economic Studies, 41(1), 57-79. https:// doi.org/10.1080/00074910500072690.

Guo, S. Y., \& Fraser, M. W. (2014). Propensity score analysis: Statistical methods and applications (vol 11). Thousand Oaks, CA: SAGE.

Hofman, B., \& Kaiser, K. (2004). The making of the 'big bang' and its aftermath: A political economy perspective. In J. Alm, J. Martinez-Vazquez, \& S. M. Indrawati (Eds.). Reforming intergovernmental fiscal relations and the rebuilding of Indonesia. Cheltenham, UK: Edward Elgar Publishing, p. 3152. https://doi.org $/ 10.4337 / 9781845421656.00007$.

Hong, G. (2012). Marginal mean weighting through stratification: A generalized method for evaluating multivalued and multiple treatments with nonexperimental data. Psychological Methods, 17(1), 4460. https://doi.org/10.1037/a0024918.

Jeong, D. W., Lee, H. J., \& Cho, S. K. (2017). Education decentralization, school resources, and student outcomes in Korea. International Journal of Educational Development, 53, 12-27. https://doi. org/10.1016/j.ijedudev.2016.12.003.

Kristiansen, S., \& Pratikno, P. (2006). Decentralising education in Indonesia. International Journal of Educational Development, 26(5), 513-531. https://doi. org/10.1016/j.ijedudev.2005.12.003.

Kurniawati, S., Suryadarma, D., Bima, L., \& Yusrina, A. (2018). Education in Indonesia: A white elephant? Journal of Southeast Asian Economies, 35(2), 185199. https://doi.org/10.1355/ae35-2e.

Kusumawardhani, P. N. (2017). Does teacher certification program lead to better quality teachers? Evidence from Indonesia. Education Economics, 25(6), 590-618. https://doi.org/10.1080/09645292.2017.1 329405.

Leer, J. (2016). After the Big Bang: Estimating the effects of decentralization on educational outcomes in Indonesia through 
a difference-in-differences analysis. International Journal of Educational Development, 49, 80-90. https://doi. org/10.1016/j.ijedudev.2016.02.005.

Lestarini, A. H. (2014, 17 April). Berbagai masalah UN di daerah pada 2013 \& 2014. [Various problems of national examinations in many regions on 2013 and 2014]. Oke News. https://news.okezone. com $/ \mathrm{read} / 2014 / 04 / 17 / 560 / 971988 /$ berbagai-masalah-un-di-daerahpada-2013-2014.

Nakajima, N., Hasan, A., Jung, H., Brinkman, S., Pradhan, M., \& Kinnell, A. (2019). Investing in school readiness: A comparison of different early childhood education pathways in rural Indonesia. International Journal of Educational Development, 69, 22-38. https://doi. org/10.1016/j.ijedudev.2019.05.009.

Pradhan, M. P., \& de Ree, J. (2014, July). District governance and student learning in Indonesia (Economics Working Paper Series No. 397). Manila, Philippines: Asian Development Bank. https://doi. org/10.2139/ssrn.2479722.

Qoyyimah, U. (2018). Policy implementation within the frame of school-based curriculum: A comparison of public school and Islamic private school teachers in East Java, Indonesia. Compare: $A$ Journal of Comparative and International Education, 48(4), 571-589. https://doi.org /10.1080/03057925.2017.1334536.

Rahman, A. A. (2019). Decentralised education policy in Indonesia: Intended outcomes and remaining challenges. Exchanges: The Interdisciplinary Research Journal, 6(2), 30-47. https://doi.org/10.31273/eirj. v6i2.240.

Retnawati, H. (2016). Hambatan guru Matematika sekolah menengah pertama dalam menerapkan kurikulum baru. [Obstacles of Mathematic secondary school teachers in implementing new curriculum]. Cakrawala Pendidikan, 34(3), 390-403. https://doi.org/10.21831/ cp.v3i3.7694.
Rosenbaum, P. R., \& Rubin, D. B. (1983). The central role of the propensity score in observational studies for causal effects. Biometrika, 70(1), 41-55. https://doi. org/10.2307/2335942.

Rosenbaum, P. R., \& Rubin, D. B. (1984). Reducing bias in observational studies using subclassification on the propensity score. Journal of the American Statistical Association, 79(387), 516-524. https:// doi.org/10.2307/2288398.

Setiawan, A., Widjaja, S. U. M., Kusumajanto, D. D., \& Wahyono, H. (2020). The effect of Curriculum 2013 on economics learning achievement: Motivation as mediating variable. Cakrawala Pendidikan, 39(2), 444-459. $\quad$ https://doi.org/10.21831/ cp.v39i2.30279.

Sirait, S. (2016). Does teacher quality affect student achievement? An empirical study in Indonesia. Journal of Education and Practice, 7(27), 34-41. https://ssrn.com/ abstract=2846795.

Skoufias, E., Narayan, A., Dasgupta, B., \& Kaiser, K. (2011, March). Electoral accountability, fiscal decentralization and service delivery in Indonesia (Policy Research Working Paper Series 5614). The World Bank. https://doi. org/10.1596/1813-9450-5614.

Strauss, J., Witoelar, F., \& Sikoki, B. (2016). The fifth wave of the Indonesia family life survey: Overview and field report (Working paper WR-1143/1-NIA/ NICHD). Santa Monica, CA: RAND Corporation. https://doi.org/10.7249/ WR1143.1.

Subijanto, S. (2010). Prinsip-prinsip dan efektivitas desentralisasi pendidikan dalam rangka meningkatkan mutu dan relevansi pendidikan. [The principles and effectiveness of education decentralization in order to improve the quality and relevance of education]. Jurnal Pendidikan dan Kebudayaan, 16(5), 532-549. https://doi.org/10.24832/ ipnk.v16i5.484. 
Suryadarma, D. (2012). How corruption diminishes the effectiveness of public spending on education in Indonesia. Bulletin of Indonesian Economic Studies, 48(1), 85-100. https://doi.org/10.1080/00 074918.2012.654485.

Suryadi, B. (2013). Evaluasi penyelenggaraan ujian nasional tahun 2013. [Evaluation of national examination 2013]. http:// repository.uinjkt.ac.id.

Wahyuni, F. (2015). Kurikulum dari masa ke masa (Telaah atas pentahapan kurikulum pendidikan di Indonesia). [Curriculum from time to time (An analysis of the stages of the education curriculum in Indonesia)]. Al-Adabiya, 10(2), 231242. http://ejournal.kopertais4.or.id/ mataraman/index.php/alabadiyah/article/ view/2792.

Wajdi, M. B. N., Kuswandi, I., Faruq, U. A., Zulhijra, Z., Khairudin, K., \& Khoiriyah, K. (2020). Education policy overcome coronavirus, A study of Indonesians.
EDUTEC: Journal of Education and Technology, 3(2), 96-106. https://doi. org/10.29062/edu.v3i2.42.

Xie, Y., Brand, J.E., \& Jann, B. (2012). Estimating heterogeneous treatment effects with observational data. Sociological Methodology, 42(1), 314-347. https://doi. org/10.1177/0081175012452652.

Yeom, M., Acedo, C., Utomo, E., \& Yeom, M. (2002). The reform of secondary education in indonesia during the 1990s: Basic education expansion and quality improvement through curriculum decentralization. Asia Pacific Education Review, 3(1), 56-68. https://doi. org/10.1007/BF03024921.

You, Y., \& Morris, P. (2016). Imagining school autonomy in high-performing education systems: East Asia as a source of policy referencing in England. Compare: $A$ Journal of Comparative and International Education, 46(6), 882-905. https://doi.org /10.1080/03057925.2015.1080115. 